\title{
METHODOLOGICAL ROLE OF SOCIO-GEOGRAPHICAL SYSTEMS IN THE MANAGEMENT OF REGIONAL DEVELOPMENT
}

\author{
'Ivan DUDNIK, '2Oksana BORISYUK \\ National Aviation University, Kyiv, Ukraine \\ 'dudnik_ivan@ukr.net, 2imv2008@ukr.net
}

\begin{abstract}
The article grounds the need to study a socio-geographical system being a complex and heterogenous formation as an integral object of regional regional management. The analysis reflects necessary conditions for origin and development of sociogeographic systems; backbone links, structure, main functions. There is proposed a variant of human geographical interpretation of the general management theory in the sphere of regional development.
\end{abstract}

Key words: human geography, socio-geographical system, socio-geographical study, region, management

UDC: $911.3(045)$

\section{МЕТОДОЛОГІЧНА РОЛЬ КАТЕГОРІЇ „СУСПІЛЬНО-ГЕОГРАФІЧНА СИСТЕМА» В УПРАВЛІННІ РОЗВИТКОМ РЕГІОНУ}

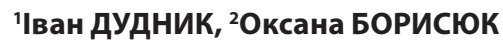 \\ Начіональний авіачійний університет, Київ, Україна \\ 'dudnik_ivan@ukr.net, ${ }^{2 i m v 2008 @ u k r . n e t ~}$
}

\begin{abstract}
Анотація: Обґрунтовується необхідність дослідження суспільно-географічної системи, як складного різноякісного утворення, в якості інтегрального об'єкта регіонального управління. Аналізуються необхідні умови зародження та розвитку суспільно-географічних систем; системотворчі зв'язки , структура , головні функції. Подається варіант суспільно-географічної інтерпретації загальної теорії управління в контексті регіонального розвитку.

Ключові слова: суспільна географія, суспільно-географічна система, суспільно-географічне дослідження, регіон,
\end{abstract} управління

Удк: $911.3(045)$

Вступ. Постановка проблеми. Зорієнтованість господарського розвитку на соціальні пріоритети; ускладнення взаємодії технічних, природних, соціальних, демографічних об`єктів та необхідність ïх збалансованого розвитку в умовах цілісної території; виникнення якісно нових завдань в розвитку сфери послуг зумовили появу такого виду управлінської діяльності, як управління комплексним розвитком регіону. Однією 3 проблемних особливостей такого виду недостатньо чітке наукове обгрунтування регіону як об'єкту управління. Помітний внесок в таке обгрунтування здійснюють представники різних наук. Однак вони не досягають належного узагальнення регіону як синергетичної різноякісної територіальної системи. Наукове вирішення такого завдання вбачається великою мірою співзвучним сучасним засадничим теоретико-методологічним положенням суспільної географії. Однією 3 необхідних умов досягнення ефективного розвитку суспільства в цілому та його територіальних складових, зокрема, є вдосконалення управління цілісними територіями (регіонами), яке грунтується на науковому передбаченні потенціалу таких територій. Управління регіоном об єктивно базується на комплексному підході, який передбачає, по-перше, врахування (оцінку, прогнозування) сукупності багатоманітних умов i факторів

(C) I. Дудник, О. Борисюк (природно-ресурсних, демографічних, соціальних, господарських), що визначають інтегральний потенціал території; по-друге, визначення шляхів досягнення цілей розвитку регіону - соціальних, екологічних, економічних; по-третє, узгодження цих цілей в галузевому, територіальному та інтегральному аспектах.

Аналіз останніх досліджень і публікацій. Початок наукової постановки проблем управління комплексним розвитком адміністративних одиниць припадає на кінець 60-х початок 70-х років минулого століття. Одними з перших вийшли роботи практичних управлінців, суспільствознавців, економістів (Е. Аграновський, В. Музичкін, М. Василів, Л. Мушкетик, М. Долішній, М. Тимчук) Важливо зауважити, що представники на той час економічної географії були серед піонерів цієї тематики поряд 3 економістами та практиками управління. Так, ще в 1984 р. П. Волобой та В. Поповкін наголошували що «...економіко-географи, як ніякі інші спеціалісти, можуть принести величезну користь всій справі вдосконалення територіального планування...» [6, с. 41]. 3 того часу з'явилася велика кількість публікацій 3 даної тематики, до неї долучилися представники соціології, екології, інших дещо вужчих наукових напрямків. Зокрема, серед географів варто назвати роботи Е. Алаєва та М. Чаадаєва [1], С. Мохначука [4].

Дещо пізніше почався масовий вихід у світ 
робіт географів спочатку у вигляді наукових статей (В. Гарабцов, I. Дудник, С. Мохначук, М. Пістун), в яких аналізувались окремі аспекти управління і планування переважно мікрорегіонами. Монографічному суспільно-географічному дослідженню низових районів присвячені роботи I. Дудника; В. Лузана, М. Пістуна, Н. Провотар, Т. Панасенко, пізніше - К. Мезенцева, Д. Стеченка тощо. Однак, попри масовість публікацій, вони не переросли в створення завершеної теорії управління суспільно-географічними системами.

Формулювання цілей статті. Постановка завдання. В умовах ринкової трансформації суспільства в Україні практичне значення названих i подібних їм робіт суттєво звузилось, оскільки вони відображали принципово інші умови функціонування регіонів. В нинішніх умовах можна говорити про загальнометодологічне значення таких робіт, яке, однак, не вирішує багатьох конкретнонаукових завдань управління розвитком регіону. Недоліком переважної більшості досліджень, і географічних в тому числі, є вкрай недостатня увага обгрунтуванню сутності та специфіки власне регіону як об'єкту управління, а в суспільній географії на початковій стадії дослідження знаходяться проблеми суспільно-географічної інтерпретації загальної теорії управління в контексті управління комплексним розвитком регіону.

Метою статті є спроба показати методологічне значення категорії «суспільно-географічна система» для потреб управління розвитком регіону як інваріантного об'єкта управління на основі суспільногеографічної методології.

Виклад основного матеріалу. В сучасних умовах розвитку суспільної географії дедалі більшої прихильності вчених набуває точка зору про те, що найбільш загальним та в той же час змістовно визначеним обєктом даної науки є суспільногеографічна система [5]. Еволюція поглядів на об єкт соціально-економічної географії $\epsilon$, по-перше, відображенням діалектичної єдності процесів диференціації та інтеграції людської діяльності (в широкому розумінні); по-друге, вона відображує розширення, поглиблення та ускладнення теоретичних уявлень про об`єкт та предмет даної науки у відповідності із соціальним замовленням.

Послідовну зміну (впродовж відповідних періодів розвитку економічної географіï) таких категорій як «виробничо-територіальний комплекс», «територіально-виробничий комплекс», «економікогеографічна система», «територіальна соціальноекономічна система», «суспільно-територіальна система (комплекс)» можна розглядати як ілюстрацію еволюції уявлень про об єкт цієї науки. Виходячи 3 оцінки сучасного рівня розвитку теорії економічної і соціальної географії, фактичних та потенційних можливостей застосування результатів iii досліджень, а також зі змісту процесів територіальної диференціації та інтеграції життєдіяльності суспільства, виявів системо- та комплексотворенням можна стверджувати, що найбільш загальним (інтегрованим) і1ï об`єктом є суспільно-географічна система. А сам термін «економічна і соціальна географія» змістовно трансформується в термін «суспільна географія».

Під суспільно-географічною системою (СГС) слід розуміти закономірний взаємозв'язок різноякісних видів та об єктів людської діяльності в умовах цілісної території, що функціонально зорієнтовані на забезпечення потреб конкретної спільності людей. В найбільш загальному вигляді суспільногеографічна система являє собою взаємозв'язану сукупність різноякісних за своєю субстанційною природою елементів (природних, демографічних, господарських), їх властивостей та відношень, яка в результаті взаємозв'язків утворює нову якість, що виявляється у відносній стійкості, територіальній та функціональній цілісності, особливому вияві закономірностей розвитку даної цілісності. Суспільно-географічна система зароджується та функціонує в результаті складних процесів взаємодії територіальних поєднань природних ресурсів, господарсько-територіальних систем, демогеографічних систем, які розглядаються як ii субстанційні підсистеми [3].

Взаємодія знаходить вираз в циркулюванні досить великої множини зв`язків (прямих, зворотних, вторинних) між матеріально - речовинними об єктами. Специфікою таких зв'язків $є$ їх істотна опосередкованість територією. Загальновизнано, що основою формування таких систем є два типи зв`язків: а) між функціональними підсистемами (вертикальні); б) між «центральним» населеним пунктом та «пересічними» поселеннями, що тяжіють до нього, знаходяться в зоні його впливу (горизонтальні) [2].

Необхідними умовами зародження та розвитку СГС є наявність:

- елементарних об єктів природної, господарської та демографічної якості;

- території відповідного розміру (масштабу), що являє собою певну природну, господарську (часто адміністративну) єдність;

- територіального «накладання» полів впливу матеріально - речовинних компонентів, якпередумови їх взаємодії;

- територіальної диференціації (спеціалізації) функцій однорідних (одноякісних) компонентів;

- інтегрально-територіальних утворень в межах певної території (системи).

Процес суспільно-географічного системоутворення базується на основі взаємодії природних, господарських, соціальних та демографічних об єктів в умовах конкретної території, яка в багатьох випадках являє собою адміністративну цілісність. Взаємодія знаходить вираз в циркулюванні досить великої множини зв'язків (прямих, зворотних, вторинних) між матеріально - речовинними об'єктами. Специфікою таких зв`язків є їх істотна опосередкованість територією. Загальновизнано, що основою формування таких систем є два типи зв`язків: а) між функціональними підсистемами (вертикальні); б) між «центральним» населеним пунктом та «пересічними» поселеннями, що 
тяжіють до нього, знаходяться в зоні його впливу (горизонтальні). Центром системи відповідного рівня є місто, як ядро системоутворення [3].

В контексті управління комплексним розвитком регіону $є$ всі підстави визнати необхідність суспільно-географічної інтерпретації загальної теорії управління. При цьому слід виходити 3 наступних положень:

1. Свідоме управління здійснюється в складних високоорганізованих системах, які при цьому розглядаються в декількох аспектах: системнокомпонентному, системно-функціональному, системно-інтегративному [3]. Управління - це процес досягнення заданого (наперед визначеного на основі прогнозу) стану об єкту (системи) в певний проміжок часу, внаслідок впливу на нього 3 допомогою необхідних засобів з боку субєкта. Управління - це протидія ентропії та дезорганізації системи, воно спрямоване на підвищення життєдіяльності системи, збереження її якісної визначеності. Тобто, управління - це впорядкування системи, досягнення такого іiі стану, який найбільше відповідав би як об`єктивним законам іï внутрішнього розвитку, так і умовам зовнішнього середовища [3]. Таким чином самокерована система складається 3 керуючої (суб `кт) та керованої (об єкт управління) підсистем, а необхідною умовою їі функціонування $є$ циркуляція інформації (інформаційні зв`язки) між суб єктом та об єктом управління.

2. Існують різні погляди щодо ролі суспільної географії у вирішенні проблем управління. Їх можна звестидодвохпідходів. Однагрупафахівціввважає,що у відповідності з вирішенням трьох головних завдань (раціональне розселення, розміщення виробництва, природокористування) географічна розробка проблем управління буде знаходитись в межах відповідних напрямків - управління демографічними процесами та розселенням людей; суспільним виробництвом та природним середовищем [1]. При цьому справедливо зауважується, що мова йде не про управління взагалі, а про просторові аспекти управління у відповідних сферах.

Ми далекі від думки брати під сумнів таке твердження, тим більше, що в сучасних умовах це $€$ однією 3 найпоширеніших форм участі соціально - економічної географії у практичному вирішенні проблем управління. Але в той же час необхідно зауважити, що обгрунтуванням лише просторових рішень не повинна обмежуватись участь географії в даному виді діяльності. Адже в такому підході відсувається на задній план умова розвитку об`єктів управління як комплексних утворень.

Інший підхід передбачає ширшу трактовку, відповідно до якої головним $є$ управління географічними об єктами [4], що передбачає розгляд будь-якого територіального утворення як певної географічної системи, що має якісну своєрідність субстанційного складу та вияву закономірностей функціонування.

Названі підходи взаємно доповнюють один одного. Вони дозволяють сформулювати найбільш загальні завдання суспільно-географічного опрацювання проблем управління, до яких відносяться, по-перше, розробка наукових основ теорії і методів управління географічними об єктами; по-друге, дослідження суспільно-географічних систем 3 позиції загальної теорії управління 3 метою пізнання їх закономірностей та специфіки функціонування як самокерованих систем; по-третє, дослідження всього спектру географічних виявів в управлінні «негеографічними» об'єктами в рамках єдності: природа - населення - господарство [2].

3. Загальним об'єктом управління виступає регіон, як міждисциплінарна категорія, яка $з$ позицій географічного мислення, 3 позицій суспільної географії розглядається як суспільно-географічна система.

4. 3 позицій суспільної географії процес управління можна визначити як цілеспрямовану діяльність для досягнення заданої мети в розвитку суспільно-географічної системи (комплексу). Суть такого управління полягає в специфічному механізмі, який реалізує вимоги географічних законів та закономірностей, в цілеспрямованому впливі на окремі елементи системи, який забезпечує iï збереження та «рух» в бажаному напрямі.

Суспільно-географічна система повинна розглядатися як самокерована система, що включає об єкт управління (СГС в традиційному розумінні) та суб єкт управління (сукупність спеціально створених людиною органів територіального i галузевого управління). Специфіка об єкта управління в даному випадку зумовлює одну 3 найістотніших особливостей управління - узгодження «інтересів» різноякісних за своїм змістом компонентів, які складають об єкт управління.

5. Управління географічними об`єктами є циклічним процесом. Цикл управління включає послідовно взаємопов'язані стадії: визначення та попереднє вивчення об'єкту - обгрунтування мети його розвитку - передбачення поведінки об`єкту в майбутньому (суспільно-географічний прогноз) - прийняття (власне планування) рішень та визначення засобів їх виконання - вивчення наслідків управляючого впливу та регулювання поведінки об єкту.

Вивчення об єкта управління та обгрунтування мети його розвитку повинні базуватись на змістовній сутності та специфічних виявах закономірностей його існування. В найбільш загальному розумінні головною метою управління $\epsilon$ оптимізація функціонування суспільно-географічної системи, тобто досягнення певного iï стану, заданих параметрівівластивостейпринайменшихзатратах [2], тобто забезпечення відносно найсприятливіших умов для функціонування системи в цілому та кожного іiі компоненту, зокрема.

6.Управління суспільно-географічними системами повинне базуватися на певних принципах, які, виходячи із загальних принципів теорії управління, відображають специфіку об єкта. Аналіз існуючих небагатьох публікацій з цього питання [1], [3], [2], [4] дає підстави для формулювання наступних принципів управління географічними об`єктами: 
комплексності; пропорційності; збереження компонентів суспільно-географічних систем; соціальної пріоритетності; принцип єдності фізикогеографічного, суспільно-географічного, соціальноекономічного, демографічного, екологічного аспектів управління.

Наведені принципи доцільно розглядати як загальні правила (вимоги) управління суспільногеографічними системами, в процесі якого необхідно враховувати їх логічний взаємозв'язок та взаємну підпорядкованість. На основі таких загальних принципів в подальшому формулюються більш конкретні принципи, які відображують специфіку конкретного об'єкта у відповідності до певного етапу управління.
Висновки і перспективи подалыших розвідок. Отже, подальше суспільно-географічне вивчення та розкриття проблем управління комплексним розвитком регіонів, на наш погляд, повинне органічно поєднувати наукову розробку наступних напрямків:

- поглиблення теоретико-методологічних основ функціонування СГС;

- створення новітньої системи методів та методик їх дослідження;

- конкретизація змісту комплекснопропорційного розвитку та засобів його досягнення;

- поглиблення змісту, цілей та засобів управління $\mathrm{CГC}$;

- вдосконалення географічної методології та методів прогнозування.

\section{References:}

1. Alaev È. B., Čaadaeva N. V. Voprosy upravleniâ i rešenie ih geografičeskoj naukoj [Management issues and their solutions by geographical science]. Voprosy geografii [Issues of Geography], 1978, Vol. 109, pp. 61-79. (In Russian).

2. Dudnik İ. M. Suspil'no-geografǐcnì sistemi nizovogorìvnâ(teoretičnì tametodičnì aspekti) [Socio-geographical system at the grass-roots level (theoretical and methodological aspects)]. Poltava, 1997, 249 p. (In Ukrainian).

3. Dudnik İ. M. Vstup do zagal'noï teorï sistem: navčal'nij posibnik [Introduction to general systems theory: Textbook]. Kyiv, 2009, 205 p. (In Ukrainian).

4. Mohnačuk S. S. Problemy upravleniâ geografičeskimi ob'ektami [Geographical objects: management problems]. Èkonomičeskaâ geografiâ: Respublikanskij mežvedomstvennyj naučnyj sbornik [Economic geography: the Republican interdepartmental scientific collection], 1982, Vol. 33, pp. 5-20. (In Russian).

5. Pìstun M. D. Osnovi teoriï suspil'noï geografï [Theoretical fundamentals of human geography]. Kyiv, 1996, 231 p. (In Ukrainian).

6. Voloboj P. V., Popovkin V. A. Geografičeskie osnovy kompleksnogo territorial'nogo planirovaniâ [Geographical outlines of integrated territorial planning]. Problemy perspektivnogo territorial'nogo planirovaniâ. Materialy Vsesoûznoj konferencii [The problems of long-term spatial planning. Proceedings of all-Union conference], Moscow, 1984, pp. 35-41. (In Russian). 